\title{
THE EFFECTIVENESS OF ACUPUNCTURE THERAPY ON WEIGHT REDUCTION AMONG OBESE PATIENTS IN MOJOKERTO, EAST JAVA
}

\author{
Indah Kusmindarti ${ }^{1)}$ Enny Virda Yuniarti2) \\ 1)Department of Maternity Nursing, STIKES Bina Sehat PPNI, Mojokerto \\ ${ }^{2)}$ Department of Medical Surgical Nursing, STIKES Bina Sehat PPNI, Mojokerto
}

\begin{abstract}
BACKGROUND: Obesity is an abnormal or excessive fat accumulation within an individual's body that may impair health. Obesity is widely known as a risk factor of many chronic diseases, including hypertension, other cardiovascular diseases, and diabetes mellitus. Globally in 2014, more than 1.9 billion adults, 18 years and older, were overweight. Of these over 600 million were obese. As many as 39\% of adults aged 18 years and over were overweight in 2014, and $13 \%$ were obese. As many as 41 million children under the age of 5 were overweight or obese in 2014. Obesity is preventable and curable. This study aimed to determine the effect of acupuncture therapy on weight reduction among obese patients.

SUBJECT AND METHODS: This was a quasi-experiment with before and after design, conducted at Yayasan Terapi Zona, Mojokerto, East Java. A sample of 30 obese patients was selected for this study. The independent variable was a series of 12 time acupuncture therapy. The dependent variable was body weight, measure by manual body weight scale. The change in body weight $(\mathrm{kg})$ before and after acupuncture therapy was tested for statistical significance by t-test.
\end{abstract}

RESULTS: Age of the study subjects ranged from 18 to 25 years old. The body weight $(\mathrm{kg})$ of the study subjects reduced from mean=65.2 $(\mathrm{SD}=9.64)$ $\mathrm{kg}$ before therapy to mean=62.2 $(\mathrm{SD}=9.51) \mathrm{kg}$ after therapy, and it was statistically significant $(\mathrm{p}=0.047)$.

CONCLUSION: A series of 12 time acupuncture therapy can effectively reduce body weight among obese patients.

Keywords: obesity, weight reduction, acupuncture therapy 